\title{
PENDEKATAN EKONOMI WILAYAH DALAM PERENCANAAN PEMBANGUNAN KOTA SAMARINDA ${ }^{1}$
}

\section{REGIONAL ECONOMIC APPROACH IN DEVELOPMENT PLANNING IN SAMARINDA MUNICIPALITY}

\author{
Maria Agustini Permata Sari, Mayahayati Kusumaningrum, dan Lia Rosliana
}

PKP2A III Lembaga Aministrasi Negara

JI. H.M Ardans (Ring Road III) Samarinda-Kalimantan Timur

Email: sari_anur@yahoo.com

Naskah diterima: 28 April 2016, revisi pertama: 24 Oktober 2016, revisi kedua: 18 November 2016

\begin{abstract}
For the last ten years, mining and processing industry has become the biggest contributor in economic sectors for Samarinda after trading, restaurant and hotel. But in fact, both sectors have been decreasing due to the lack of resources. This study aims to capture the development of the sub-districts based on their local potential and development by using qualitative method. The focus of this study is to identify the local potential based on economic sectors (agriculture, processing industry; trading and restaurant; and transportation and communication). In collecting the data, this study makes use the secondary data that are collected from various literatures. The results are that the mapping of the development of the districts in Samarinda based on its economic potential can be grouped or defined into three economic clusters: Leading Cluster, Potential Cluster and Opportunity Cluster.
\end{abstract}

Keywords: regional economic, development planning.

\begin{abstract}
Abstrak
Sepuluh tahun terakhir lapangan usaha yang menjadi penyumbang ekonomi terbesar di Kota Samarinda setelah perdagangan, restoran dan hotel adalah pertambangan, dan industri pengolahan. Namun pada kenyataannya tren kedua sektor tersebut semakin menurun dikarenakan kesulitan memperoleh bahan baku. Studi ini bertujuan untuk melihat pemetaan pembangunan wilayah kecamatan berdasarkan potensi dan pengembangannya, dimana fokus studi ini adalah pada upaya menemukenali potensi daerah berdasarkan
\end{abstract}

\footnotetext{
${ }^{1}$ Artikel ini disarikan dari hasil kajian PKP2A III LAN dengan BLDD Kota Samarinda Tahun 2015 berjudul "Kajian Perencanaan Pembangunan Wilayah Berdasarkan Pendekatan Ekonomi dengan Dasar Potensi dan Pengembangannya”.
} 
sektor ekonomi (pertanian; industri pengolahan; perdagangan dan restoran; serta pengangkutan dan komunikasi). Studi ini menggunakan metode kualitatif. Pengumpulan data menggunakan data sekunder yang dikumpulkan dari berbagai literatur. Hasil studi ini menyimpulkan bahwa pemetaan pembangunan wilayah kecamatan di Kota Samarinda berdasarkan potensi ekonomi yang dimilikinya dapat dikelompokkan atau ditetapkan ke dalam 3 cluster ekonomi, yaitu Leading Cluster, Potential Cluster, dan Opportunity Cluster.

Kata kunci: ekonomi wilayah, perencanaan pembangunan.

\section{A. PENDAHULUAN}

Menurut Undang-undang No 26 Tahun 2007 tentang penataan ruang, setiap daerah Kabupaten dan Kota perlu menyusun rencana tata ruangnya sebagai arahan pelaksanan pembangunan. Dalam perencanaan pembangunan, baik itu perencanaan nasional maupun perencanaan daerah, dapat dilakukan dengan dua cara, yaitu pendekatan sektoral dan pendekatan regional. Pendekatan wilayah dilakukan dengan melihat pemanfaatan ruang serta interaksi-interaksi berbagai kegiatan dalam ruang suatu wilayah, sedangkan pendekatan sektoral, fokus perhatiannya pada sektor-sektor kegiatan yang ada di wilayah tersebut dan mengelompokkan kegiatan ekonomi menurut sektor sektor yang sejenis (Iryanto, 2006).

Sejalan dengan itu, di tahun 2014 Pemerintahan Kota Samarinda telah melahirkan Peraturan Daerah Nomor 2 Tahun 2014 tentang Rencana Tata Ruang Wilayah Kota Samarinda Tahun 20142034. Dalam Perda tersebut, disebutkan bahwa kebijakan penataan ruang di Kota Samarinda diantaranya: peningkatan akses pelayanan regional dan internasional sebagai Pusat Kegiatan Nasional yang merupakan bagian dari kawasan perkotaan Balikpapan-Tenggarong-Samarinda-Bontang dan sebagai bagian dari Kapet Sasamba; perwujudan pusat-pusat pelayanan kota yang bersinergi, efektif dan efisien dalam menunjang perkembangan fungsi daerah sebagai kota tepian; serta peningkatan peran kota tepian yang ditunjang oleh kegiatan industri, pertanian, perikanan, perdagangan/jasa dan pariwisata. Adapun salah satu pertimbangan yang digunakan dalam penyusunan RTRW adalah sector ekonomi atau lapangan usaha.

Berdasarkan klasifikasi sembilan sektor ekonomi atau lapangan usaha di Kota Samarinda, sektor yang sumbangannya paling tinggi adalah sektor perdagangan, hotel dan restoran. Peranan sektor tersebut selama dua belas tahun terakhir terus meningkat. Sedangkan sektor yang mempunyai kontribusi terbesar kedua setelah perdagangan adalah industri pengolahan, namun pada kurun empat tahun terakhir, sektor ini terus turun peranannya, disebabkan oleh kendala memperoleh bahan baku, terutama untuk sektor industri kayu lapis (PDRB Kota Samarinda Menurut Lapangan Usaha, 2013). 
Tabel 1.

Struktur Sektor Ekonomi Kota Samarinda Tahun 2000, 2010-2013 (persen)

\begin{tabular}{|l|r|r|r|r|r|}
\hline \multicolumn{1}{|c|}{ Lapangan Usaha } & \multicolumn{1}{c|}{$\mathbf{2 0 0 0}$} & \multicolumn{1}{c|}{$\mathbf{2 0 1 0}$} & \multicolumn{1}{c|}{$\mathbf{2 0 1 1}$} & \multicolumn{1}{c|}{$\mathbf{2 0 1 2}$} & \multicolumn{1}{c|}{$\mathbf{2 0 1 3}$} \\
\hline \multicolumn{1}{|c|}{$(\mathbf{1})$} & \multicolumn{1}{c|}{$(\mathbf{3})$} & \multicolumn{1}{c}{$(\mathbf{3})$} & \multicolumn{1}{c|}{$(\mathbf{5})$} & \multicolumn{1}{c|}{$(6)$} \\
\hline Pertanian dan & 2,38 & 2,14 & 1,51 & 1,45 & 1,55 \\
\hline $\begin{array}{l}\text { Pertambangan } \\
\text { Penggalian }\end{array}$ & 5,39 & 8,54 & 20,92 & 14,76 & 12,07 \\
\hline Industri Pengolahan & 31,90 & 19,59 & 14,61 & 14,27 & 13,95 \\
\hline Listrik dan Air Minum & 1,55 & 1,16 & 0,92 & 0,99 & 0,93 \\
\hline Konstruksi/Bangunan & 4,16 & 5,25 & 4,05 & 4,29 & 4,42 \\
\hline $\begin{array}{l}\text { Perdagangan, Restoran \& } \\
\text { Hotel }\end{array}$ & 21,59 & 29,35 & 30,79 & 35,69 & 38,32 \\
\hline $\begin{array}{l}\text { Angkutan } \\
\text { Komunikasi }\end{array}$ & 11,02 & 9,67 & 7,45 & 7,18 & 7,18 \\
\hline Keuangan & 12,85 & 12,39 & 10,34 & 11,55 & 11,65 \\
\hline Jasa-jasa & 9,16 & 11,92 & 9,41 & 9,82 & 9,92 \\
\hline JUMLAH & 100 & 100 & 100 & 100 & 100 \\
\hline
\end{tabular}

Sumber: PDRB Kota Samarinda menurut Lapangan Usaha Tahun 2010-2013

Saat ini luas wilayah Kota Samarinda adalah $718 \mathrm{~km}^{2}$ dengan 10 (sepuluh) kecamatan. Visi Kota Samarinda adalah menjadi Kota Jasa, Industri, Perdagangan dan Pemukiman Yang Berwawasan Lingkungan. Untuk mewujudkan visi tersebut, tentu Pemerintah Kota Samarinda memerlukan perencanaan yang matang serta komprehensif, sehingga baik perencanaan, penganggaran, pelaksanaan, dan pengawasan pembangunan dapat fokus. Sebagaimana yang disampaikan oleh Pengamat Perencanaan Pembangunan dari Universitas Mulawarman, Aji Ratna Kusuma pada diskusi publik rancangan awal RPJP Kota Samarinda, bahwa Pemerintah Kota Samarinda masih belum fokus terhadap jasa dan industri apa yang nantinya akan menjadi andalan, sehingga dikhawatirkan SKPD akan 'bingung’ menurunkan dalam rencana strategis dan rencana kerja. ${ }^{2}$

Berangkat dari kondisi diatas, rumusan permasalahan dalam penelitian ini adalah bagaimana pemetaan pembangunan wilayah kecamatan di Kota Samarinda berdasarkan potensi dan pengembangannya?

\section{B. METODE PENELITIAN}

Penelitian ini menggunakan metode kualitatif. Dengan metode ini diharapkan dapat menggambarkan potensi ekonomi di masing-masing kecamatan sehingga dapat dilakukan pemetaan potensi ekonomi sebagai bahan perencanaan pembangunan wilayah. Selanjutnya pencarian sumber data dalam tulisan ini menggunakan data sekunder yang dikumpulkan dari berbagai literatur berupa laporan, buku, jurnal, artikel baik di media cetak maupun elektronik yang terkait dengan tulisan ini.

Fokus penelitian ini adalah upaya menemukenali potensi daerah (kecamatan-kecamatan di Kota Samarinda) berdasar beberapa sektor ekonomi, yang terdiri dari pertanian; industri pengolahan; perdagangan dan restoran; serta pengangkutan dan komunikasi.

\footnotetext{
${ }^{2}$ http://www.kaltimpost.co.id/berita/detail/221732-astaga-10-tahun-samarinda-tanpa-konsep.html, diunduh tanggal 14 September 2015
} 


\section{KERANGKA TEORI}

\section{Perencanaan Pembangunan}

Pembangunan saat ini tidak lagi melihat pada pencapaian pertumbuhan PDB/PDRB sebagai tujuan akhir, melainkan pengurangan (atau dalam bentuk ekstrimnya penghapusan) tingkat kemiskinan yang terjadi, penanggulangan ketimpangan pendapatan serta penyediaan lapangan kerja yang mampu menyerap angkatan kerja produktif (Widodo, 3: 2006). Untuk mencapai tujuan dari pembangunan tentunya diperlukan sebuah perencanaan yang akurat. Salah satu peran perencanaan adalah sebagai arahan bagi proses pembangunan untuk berjalan menuju tujuan yang ingin dicapai di samping tolak ukur keberhasilan proses pembangunan yang dilakukan (Widodo, 2:2006). Secara konspetual, Mintzberg (LAN, 17:2014) mendefinisikan perencanaan sebagai pemikiran tentang masa depan, pengendalian masa depan, pengambilan keputusan dan integrasi pengambilan keputusan. Sedangkan menurut Friedman (Wibawa, 87:2012) perencanaan tidak semata-mata merupakan persoalan instrumentasi sasaran-sasaran secara efisien, tapi juga suatu proses yang mungkin mengantar masyarakat menemukan masa depannya. Menurut Siswanto (Wibawa, 2014:86), proses perencanaan haruslah integratif di antara berbagai pihak yang terlibat, untuk memaksimalkan efektivitas kegiatan dari organisasi atau sistem administrasi yang bersangkutan. Selanjutnya, Conyers dan Hills (Kuncoro, 2012:50) mendefinisikan perencanaan sebagai suatu proses berkesinambungan yang mencakup keputusan-keputusan atau pilihan-pilihan berbagai alternatif penggunaan sumber daya untuk mencapai tujuan-tujuan tertentu pada masa mendatang.

Dari definisi diatas dapat diartikan perencanaan pembangunan merupakan rancangan terkait langkah-langkah serta alternatif keputusan yang dapat dilakukan di masa mendatang untuk mencapai perubahan ekonomi masyarakat ke arah yang lebih baik.

\section{Pembangunan Ekonomi Daerah}

Arsyad dalam Adisasmita (2011;20) menjelaskan bahwa pembangunan ekonomi daerah adalah suatu proses dimana pemerintah daerah dan masyarakat mengolah sumber daya yang ada dan membentuk suatu pola kemitraan antara pemerintah daerah dengan swasta untuk menciptakan suatu lapangan kerja baru dan perkembangan kegiatan ekonomi (pertumbuhan ekonomi) dalam wilayah tersebut.

Pembangunan selalu dibarengi dengan pertumbuhan akan tetapi dalam pertumbuhan, belum tentu mencakup unsur pembangunan, maka pertumbuhan ekonomi yang terus menerus serta dapat mendukung peningkatan perekonomian dan kesejahteraan rakyat merupakan tujuan paling utama dari keberlangsungan pembangunan (Adisasmita, 2011:24).

Pembangunan ekonomi sebagai upaya untuk mengembangkan kegiatan ekonomi dan taraf hidup masyarakat, secara umum dikatakan suatu perekonomian sehingga sekalipun ada satu waktu dimana peningkatan pendapatan perkapita seolah-olah terhenti namun diwaktu mendatang terjadi peningkatan, maka itu terdapat pembangunan ekonomi (Adisasmita, 2011:27). Sejalan dengan itu Bachrudin (Kuncoro 2012:204) menyebutkan skema piramida strategi pengembangan ekonomi lokal terdiri atas kemandirian masyarakat dan daerah, pemanfaatan potensi wilayah, integritas ekonomi antara daerah tertinggal dan daerah maju serta penanganan daerah khusus merupakan pondasi pembangunan piramida pengembangan ekonomi lokal, selain itu pengadaan sarana dan prasarana serta pemberdayaan masyarakat merupakan faktor ekonomi lainnya.

\section{Penataan Ruang}

Dalam pembangunan yang berwawasan lingkungan dan manusia, dikembangkan pola tata ruang yang menyeimbangkan tata guna tanah, tata guna hutan, serta tata guna sumber daya alam 
lainnya dalam satu kesatuan tata lingkungan yang harmonis dan dinamis, yang ditunjang oleh pengelolaan perkembangan kependudukan yang serasi dan harmonis. Kegiatan pendekatan wilayah ini bukan hanya mengidentifikasi fenomena atau hubungan sebab akibat terbentuknya kondisi wilayah, namun juga pemahaman dan perumusan bagaimana mengembangkan kegiatan sektor-sektor sosial budaya, ekonomi, sumber daya alam, sumber daya buatan, perlindungan lingkungan sesuai dengan kondisi sumber daya manusia, pengembangan permukiman serta rumusan pengembangan infrastruktur pendukung, seperti sistem transportasi secara terpadu yang dituangkan dalam spatial planning (Iryanto, 2006).

Direktorat Bina Tata Perkotaan dan Pedesaan Ditjen Cipta Karya yang dikutip oleh Tarigan (dalam Fitriana dkk, 2013) memberikan definisi tentang ruang sebagai wadah yang meliputi ruang daratan, ruang lautan dan ruang udara termasuk didalamnya lahan atau tanah, air, udara dan benda lainnya serta daya dan keadaan sebagai satu kesatuan wilayah tempat manusia dan makhluk lainnya hidup dan melakukan kegiatan serta memlihara kelangsungan hidupnya.

Dalam rangka mewujudkan konsep pengembangan wilayah yang didalamnya memuat tujuan dan sasaran yang bersifat kewilayahan di Indonesia, maka ditempuh melalui upaya penataan ruang yang terdiri dari tiga proses utama, yakni proses perencanaan tata ruang wilayah; proses pemanfaatan ruang; serta proses pengendalian pemanfaatan ruang(Direktur Jenderal Penataan Ruang Permukiman dan Prasarana Wilayah, 2003).

\section{Perencanaan Pembangunan Wilayah Dengan Pendekatan Ekonomi}

Tahap perencanaan adalah proses pemilihan sumber daya-sumber daya yang akan digunakan dalam mewujudkan tujuan yang diinginkan. Perencanaan merupakan alat pengalokasian sumber daya. Dengan kata lain, pada tahap perencanaan ini, dilakukan suatu proses alokasi besarnya sumber daya yang digunakan dalam perwujudan tujuan yang diinginkan. Oleh karena itu, pilihan berarti menentukan prioritas pembangunan daerah baik fokus (sektoral) maupun lokusnya (regional). Lokus memperlihatkan wilayah (kabupaten/kota/kecamatan/kawasan) yang ingin dikerjakan, sedangkan fokus memperlihatkan sektor yang menjadi prioritas (Kuncoro, 2012:50). Berikut gambar mengenai perencanaan berdasarkan sektoral dan regional.

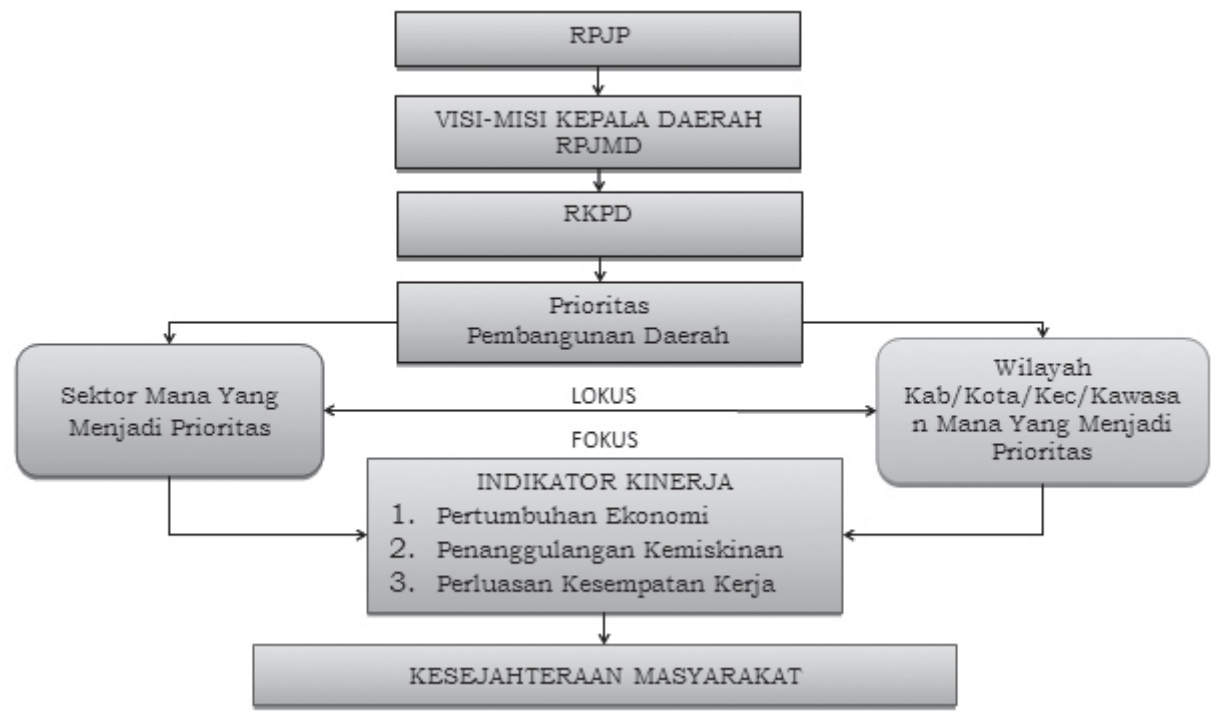

Sumber: Kuncoro (2012:42)

Gambar 1.

Contoh Perencanaan Regional dan Sektoral 
Perencanaan ekonomi adalah upaya yang dilakukan pemerintah secara sengaja dan hati-hati untuk mengkoordinasikan keputusan-keputusan ekonomi selama jangka panjang. Keputusankeputusan ekonomi tersebut ditujukan untuk mempengaruhi, mengarahkan dan dalam beberapa kasus bahkan untuk mengendalikan tingkat dan pertumbuhan variabel-variabel ekonomi utama. Selanjutnya menurut Ghalib (2005:238) tujuan pembangunan ekonomi regional/lokal yang didasarkan kepada rumusan The Organization of Economic Cooperation and Development (OECD), tahun 1986 meliputi: memperkuat posisi daya saing wilayah-wilayah dan lokasi-lokasi dalam wilayahwilayah dengan mengembangkan potensinya, yang sumberdaya alam dan manusianya masih kurang termanfaatkan; merealisasikan kesempatan-kesempatan pertumbuhan ekonomi dari dalam (endogeneous) melalui mengorganisasikan kembali kesempatan-kesempatan yang ada untuk memproduksi barang-barang dan dan jasa-jasa secara lokal; memperbaiki tingkat kesempatan kerja dan opsi-opsi pengembangan karir jangka panjang untuk penduduk lokal; meningkatkan partisipasi perekonomian lokal dari keadaan yang merugikan kelompok-kelompok minoritas; serta memperbaiki lingkungan secara fisik sebagai suatu unsur kebutuhan memperbaiki iklim pembangunan bisnis dan mempertinggi mutu hidup penduduk setempat

Wilayah dapat berkembang melalui berkembangnya sektor unggulan pada wilayah tersebut yang mendorong pengembangan sektor lainnya, sehingga pengembangan sektor menjadi salah satu pendekatan yang perlu dipertimbangkan untuk pengembangan wilayah (Djakapermana, 2010), oleh sebab itu pendekatan sektoral masih menjadi salah satu strategi dalam membangun potensi ekonomi wilayah $^{3}$

\section{HASIL DAN PEMBAHASAN}

\section{Gambaran Umum Kota Samarinda}

Kota Samarinda sebagai ibukota Provinsi Kalimantan Timur yang berbatasan langsung dengan Kabupaten Kutai Kartanegara memiliki luas wilayah 718 km2. Sebagai ibukota Provinsi, Kota Samarinda memiliki jumlah penduduk terbesar di Provinsi Kalimantan Timur yang selalu meningkat tiap tahunnya. Di tahun 2013, penduduk Samarinda mencapai 805.688 jiwa yang meningkat 3\% dari tahun 2012.

Dengan adanya perkembangan dan pemekaran wilayah, secara administratif Kota Samarinda pada tahun 2010 dibagi menjadi sepuluh kecamatan. Kecamatan Samarinda Ulu merupakan kecamatan yang memiliki kepadatan penduduk terbesar, yaitu sebanyak 6.088 jiwa/km2, sedangkan Kecamatan Samarinda Utara dan Palaran yang mempunyai wilayah lebih luas, kepadatan penduduknya hanya sekitar 246/km2 dan 435/ km2.

Kota Samarinda pada tahun 2012 memiliki 558 ribu penduduk usia kerja. Dari jumlah tersebut yang termasuk angkatan kerja sebanyak 359 ribu orang sehingga tingkat partisipasi angkatan kerja di tahun 2012 sebesar 64.35\%. Sektor ekonomi yang paling dominan dalam struktur perekonomian Kota Samarinda dan merupakan penyerap tenaga kerja terbesar yakni sektor perdagangan, rumah makan dan jasa akomodasi serta sektor jasa-jasa.

Tahun 2015 merupakan akhir dari rencana pembangunan jangka menengah daerah (RPJMD) Kota Samarinda 2010-2015. Dalam RPJMD tahun 2010-2015 Kota Samarinda memiliki visi “Terwujudnya Kota Samarinda Sebagai Kota Metropolitan Berbasis Industri, Perdagangan

\footnotetext{
${ }^{3}$ Eko Budi Santoso, Belinda Ulfa Aulia, Dian Rahmawati, dan Deny Ferdyansyah Analisis Keterkaitan Wilayah secara Sektoral Kawasan GKS Plus terhadap Jawa Timur Seminar Nasional CITIES 2012
} 
dan Jasa Yang Maju Berwawasan Lingkungan dan Hijau, mempunyai Keunggulan Daya Saing Untuk meningkatkan Kesejahteraan Masyarakat”. Visi yang termuat dalam RPJMD Kota Samarinda di tahun 2015 tersebut merujuk dari visi rencana pembangunan jangka panjang (RPJP) Kota Samarinda, yaitu sebagai “Kota Jasa, Industri, Perdagangan dan Permukiman yang Berwawasan Lingkungan”. Terlihat bahwa sasaran pokok pembangunan Samarinda sebagai daerah perkotaan, ditekankan pada sektor industri, perdagangan dan jasa.

\section{Rencana Pola Ruang Kawasan Budidaya Kota Samarinda}

Salah satu yang diatur dalam Rencana Tata Ruang Kota Samarinda adalah Kawasan Budidaya, yaitu wilayah yang ditetapkan dengan fungsi utama untuk dibudidayakan atas dasar kondisi dan potensi sumber daya alam, sumber daya manusia dan sumber daya buatan. Dalam perencanaan kawasan budidaya, masing-masing kecamatan sudah ditentukan kawasan yang diperuntukkan sebagai kawasan dengan penggunaan lahan tertentu sebagai bagian dari kegiatan manusia untuk memenuhi kebutuhannya. Peruntukkan kawasan yang dimaksud antara lain untuk kawasan permukiman; kawasan perdagangan dan jasa; kawasan pariwisata; kawasan industri; kawasan pertanian; dan kawasan pertambangan. Untuk lebih lengkapnya dapat dilihat pada Tabel 2.

Tabel 2.

Rencana Pola Ruang Kawasan Budidaya Kota Samarinda

\begin{tabular}{|c|c|c|c|c|c|c|c|c|c|c|}
\hline \multirow[b]{2}{*}{ Kecamatan } & \multicolumn{9}{|c|}{ Kawasan Budi Daya (Ha) } & \multirow[b]{2}{*}{$\begin{array}{c}\text { Luas } \\
\text { Kawasan } \\
\text { Budidaya } \\
\text { (Ha) } \\
\end{array}$} \\
\hline & $\mathbf{l}$ & 2 & 3 & 4 & 5 & 6 & 7 & 8 & 9 & \\
\hline $\begin{array}{ll}\text { Loa Janan } \\
\text { Mir }\end{array}$ & & 1,46 & 488,30 & 54,89 & 54,56 & 5,15 & $1.194,61$ & 322,26 & 135,69 & $2.256,92$ \\
\hline Palaran & & 1,53 & $\begin{array}{r}6.691,7 \\
2\end{array}$ & 156,96 & & & $5.983,28$ & $2.956,50$ & $\begin{array}{r}1277,4 \\
1\end{array}$ & $17.067,40$ \\
\hline $\begin{array}{l}\text { Samarinda } \\
\text { Mir }\end{array}$ & & & & 13,07 & & 14,65 & 273,64 & & & 301,36 \\
\hline $\begin{array}{l}\text { Samarinda } \\
\text { Kota }\end{array}$ & & 2,48 & & & & 82,80 & 179,73 & & & 265,01 \\
\hline $\begin{array}{l}\text { Samarinda } \\
\text { Seberang }\end{array}$ & & 7,18 & 21,54 & 1,93 & & 29,72 & 445,37 & 8,65 & 26,53 & 540,93 \\
\hline $\begin{array}{l}\text { Samarinda } \\
\text { Ulu } \\
\end{array}$ & & & 896,03 & 2,37 & & 164,15 & $2.994,74$ & 25,92 & 467,50 & $\begin{array}{r}4.5 \\
50,72 \\
\end{array}$ \\
\hline $\begin{array}{l}\text { Samarinda } \\
\text { Utara }\end{array}$ & 103 & 13,97 & $\begin{array}{r}4.604,7 \\
8\end{array}$ & 3,92 & 38,87 & 11,06 & $6.721,73$ & $6.141,16$ & 685,24 & $18.324,13$ \\
\hline Sambutan & & & 877,79 & & & 57,03 & $6.120,42$ & 602,37 & 356,47 & $8.014,08$ \\
\hline $\begin{array}{l}\text { Sungai } \\
\text { Pinang }\end{array}$ & & & 46,83 & 14,86 & & & $2.184,48$ & 250,53 & 181,55 & $2.678,26$ \\
\hline $\begin{array}{l}\text { Sungai } \\
\text { Kunjang }\end{array}$ & & & $\begin{array}{r}1.303,7 \\
5\end{array}$ & 165,78 & & 118,10 & $3.649,66$ & 77,43 & 449,76 & $5.764,48$ \\
\hline
\end{tabular}

Keterangan :

1. Bandara

2. Daerah Militer

3. Hutan Rakyat

4. Industri

5. Pariwisata
6. Perdagangan dan Jasa

7. Permukiman

8. Pertanian

9. Tambang

Sumber: Laporan Akhir Revisi Materi Teknis danAlbum Peta RTRW Kota Samarinda Tahun 20132033. 


\section{Kondisi perekonomian Kota Samarinda}

Salah satu indikator penting untuk mengetahui kondisi ekonomi di suatu daerah dalam suatu periode tertentu adalah data Produk Domestik Regional Bruto (PDRB), baik atas dasar harga berlaku maupun atas dasar harga konstan. PDRB pada dasarnya merupakan jumlah nilai tambah (value added) yang dihasilkan oleh seluruh unit usaha dalam suatu daerah tertentu, atau merupakan jumlah nilai barang dan jasa akhir (neto) yang dihasilkan oleh seluruh unit ekonomi (Widodo, 2006:78).

Selama kurun waktu empat tahun terakhir, perekonomian Kota Samarinda berkembang cukup pesat, yang ditunjukkan oleh besaran PDRB yang terus meningkat sejak tahun 2010-2013. Selama periode tersebut, Kota Samarinda mengalami pertumbuhan ekonomi rata-rata sebesar 7,62 persen per tahun, yang disebabkan oleh kegiatan ekonomi Kota Samarinda yang selalu tumbuh di hampir setiap lapangan usaha sektor ekonomi.

Pertumbuhan ekonomi pada tahun 2013 berasal dari peningkatan aktivitas beberapa sektor ekonomi di Kota Samarinda. Pertumbuhan yang tinggi terutama di sektor dominan, seperti sektor perdagangan, hotel dan restoran, dengan kontribusi terhadap pertumbuhan ekonomi Kota Samarinda yang cukup besar dan juga sektor konstruksi. Laju pertumbuhan PDRB Kota Samarinda menurut lapangan usaha dapat dilihat pada tabel 3:

Tabel 3.

Laju Pertumbuhan PDRB Kota Samarinda Menurut Lapangan Usaha

\begin{tabular}{|l|r|r|r|}
\hline \multirow{2}{*}{ LAPANGAN USAHA } & \multicolumn{3}{|c|}{ Tahun } \\
\cline { 2 - 4 } & \multicolumn{1}{|c|}{$\mathbf{2 0 1 1}$} & \multicolumn{1}{c|}{$\mathbf{2 0 1 2}$} & \multicolumn{1}{c|}{$\mathbf{2 0 1 3}$} \\
\hline Pertanian & $-5,72$ & $-3,35$ & 12,46 \\
\hline Pertambangan \& Penggalian & 138,51 & $-21,30$ & $-11,76$ \\
\hline Industri pengolahan & 3,47 & 3,36 & 4,40 \\
\hline Listrik, Gas \& Air Bersih & 5,16 & 12,58 & 7,12 \\
\hline Konstruksi & 4,56 & 8,06 & 11,93 \\
\hline Perdagangan, Hotel \& restoran & 11,04 & 9,86 & 9,65 \\
\hline Pengangkutan \& Komunikasi & 4,09 & 2,28 & 3,64 \\
\hline Keuangan, Real Estate & 7,50 & 11,88 & 10,11 \\
\hline Jasa-jasa & 8,85 & 8,96 & 6,02 \\
\hline
\end{tabular}

Sumber: BPS, PDRB Kota Samarinda 2010-2013

Periode 2011-2013, sektor konstruksi terus mengalami peningkatan pertumbuhan ekonomi. Peningkatan pertumbuhan sektor kontruksi ini tidak terlepas dari peningkatan sektor lain yang membutuhkan jasa konstruksi, seperti sektor perdagangan, hotel dan restoran, sektor industri dan sub sektor sewa bangunan. Pergeseran sektor industri pengolahan ke sektor perdagangan, hotel dan restoran di Samarinda ini telah menggenjot sektor lain, seperti kontruksi, sektor pengangkutan dan komunikasi, sektor keuangan, seta real estate di Samarinda. Di tahun 2011, sektor pertambangan khususnya pertambangan non migas masih meningkat dari tahun 2010 dengan pertumbuhan yang sangat tinggi hingga 138,51 persen, namun merosot di tahun 2012 dan lanjut di tahun 2013. Sementara sektor perdagangan, hotel dan restoran justru meningkat pesat, khususnya sub sektor perdagangan dan restoran. Posisi Kota Samarinda yang menjadi hinterland dari daerah lain seperti Kota Bontang, Kabupaten Kutai Kartanegara, Kutai Timur menjadikan sektor perdagangan, hotel restoran di Samarinda meningkat. Daya tarik tempat perbelanjaan dan hiburan bagi masyarakat Samarinda, masyarakat Kukar, Kutim, Bontang serta daerah lain terus menggenjot sektor ini. Hal ini juga berefek pada meningkatnya sub sektor bank (perbankan) serta real estate di Samarinda. Pendapatan regional 
per kapita Kota Samarinda meningkat dari tahun 2010 hingga 2013, dari Rp.30.634.205 menjadi Rp.49.541.003, bisa dikatakan kemampuan masyarakat Kota Samarinda juga meningkat, sehingga selain daya tarik sektor perdagangan, kemampuan masyarakat yang meningkat ini menggenjot sub sektor real estate di Samarinda.

\section{Potensi Ekonomi di Kecamatan Kota Samarinda}

\section{Sektor Pertanian}

Sektor pertanian merupakan salah satu sektor penting dalam perkembangan ekonomi. Untuk melihat potensi sektor pertanian beberapa sub sektor yang dijadikan acuan, antara lain: luas lahan persawahan, produksi perikanan, produksi peternakan serta unggas.

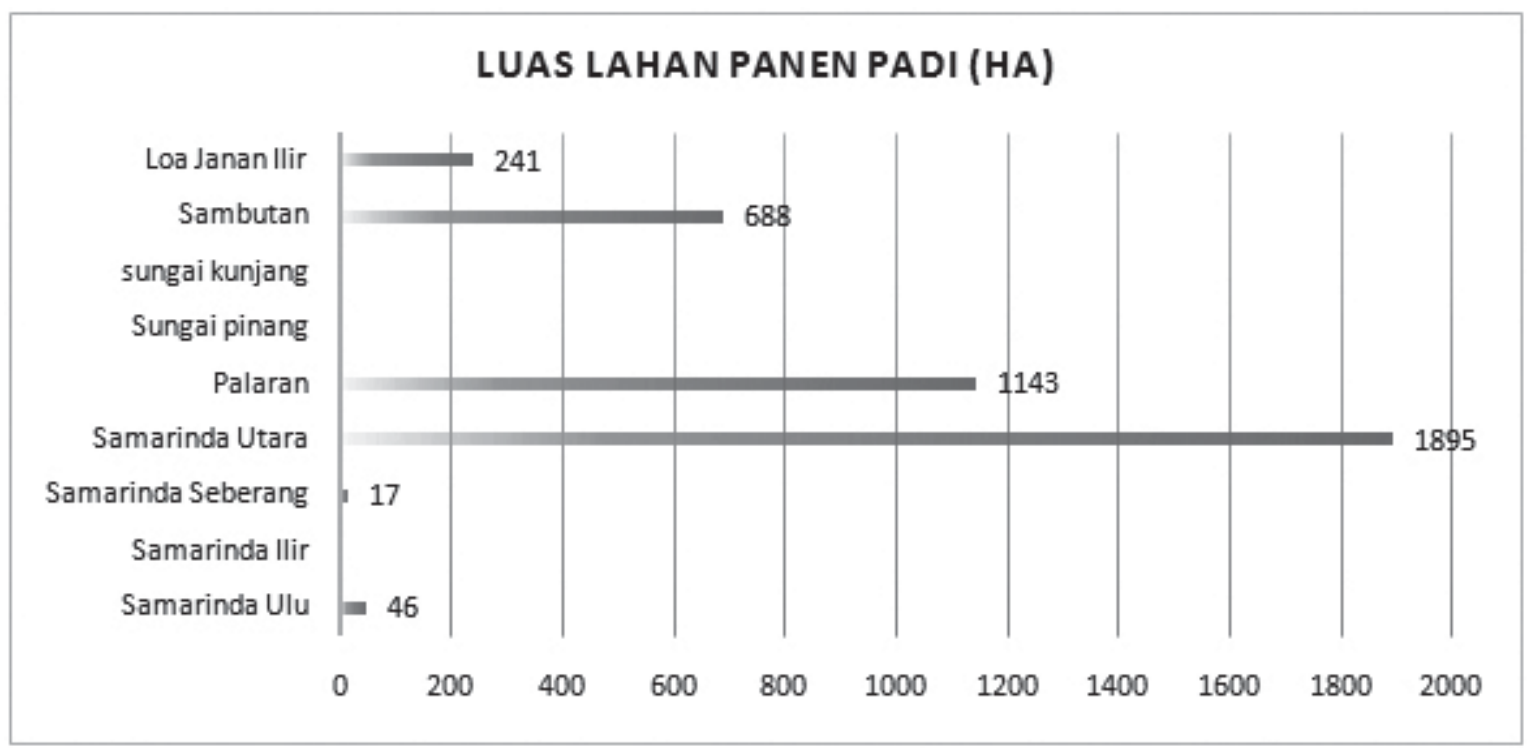

Sumber: Data diolah

Gambar 2.

Luas Lahan Panen Padi per Kecamatan di Kota Samarinda Tahun 2014

Dari tabel tentang luas lahan pertanian diketahui bahwa Kecamatan Sungai Utara memiliki luas lahan panen padi yang paling besar jika dibandingkan dengan kecamatan lainnya. Dengan lima kelurahan/desa yang dimilikinya Kecamatan Samarinda Utara merupakan sentral dari pertanian tanaman pangan yang terdiri dari tanaman padi, jagung, ketela pohon, kacang tanah, kedelai dan kacang hijau, namun yang paling banyak diusahakan oleh masyarakat Kecamatan Samarinda Utara adalah tanaman padi terutama padi sawah dan padi ladang. Adapun kecamatan yang memiliki luas lahan panen padi terbanyak kedua adalah Kecamatan Palaran.

Kecamatan Sambutan dilihat dari peningkatan luas lahan panen juga memiliki potensi di pertanian padi meskipun tidak terlalu besar, namun trend-nya cukup positif, dimana luas tanaman padi sawah dari tahun 2013-2014 mengalami kenaikan sebesar 219 Ha, sehingga luas panen meningkat menjadi 688 На.

Kecamatan Samarinda Utara dan Kecamatan Palaran juga unggul dalam sub sector perkebunan. Produk unggulan perkebunan yang paling banyak adalah tanaman perkebunan karet dan kelapa. Luas areal tanaman perkebunan untuk komoditas karet dan kelapa di Kecamatan Palaran mengalami peningkatan pada tahun 2014, sedangkan untuk tanaman lada dan kopi justru mengalami penurunan. 
Tabel 4.

Luas Lahan Perkebunan per Kecamatan di Kota Samarinda

\begin{tabular}{|l|c|c|c|}
\hline \multirow{2}{*}{\multicolumn{1}{|c|}{ Kecamatan }} & \multicolumn{3}{c|}{ Luas Lahan Perkebunan ( Ha) } \\
\cline { 2 - 4 } & $\mathbf{2 0 1 2}$ & $\mathbf{2 0 1 3}$ & $\mathbf{2 0 1 4}$ \\
\hline Samarinda Kota & - & - & - \\
\hline Samarinda Ulu & - & 48 & 51 \\
\hline Samarinda Ilir & - & - & - \\
\hline Samarinda Seberang & - & 57 & 57 \\
\hline Samarinda Utara & - & 1989 & 2027 \\
\hline Palaran & - & 846 & 890 \\
\hline Sungai pinang & - & - & - \\
\hline Sungai kunjang & - & 21 & 20,5 \\
\hline Sambutan & - & 398 & 392 \\
\hline Loa Janan Ilir & - & - & - \\
\hline
\end{tabular}

Sumber: Data diolah

Di hampir seluruh kecamatan berpotensi di perikanan darat, namun kecamatan yang produksi perikanan daratnya mengalami kenaikan dari tahun 2013 ke tahun 2014 ada di lima kecamatan, yakni Samarinda Seberang, Samarinda Ulu, Samarinda Utara, Loa Janan Ilir dan Sambutan. Kecamatan Sambutan memiliki produksi perikanan darat terbesar yaitu 1.852 ton di tahun 2014, selanjutnya Kecamatan Samarinda Seberang sebanyak 1.030 ton dan Palaran sebanyak 895,3 ton. Di sub sector perikanan laut, nilai produksi di enam kecamatan yang memiliki potensi ini, yakni Samarinda Ilir, Samarinda Seberang, Palaran, Sungai Kunjang, Sambutan dan Loa Janan Ilir, mengalami penurunan produksi di tahun 2014 dibandingkan tahun sebelumnya. Kecamatan Samarinda Seberang sebagai daerah yang produksi perikanan laut yang paling besar dengan banyaknya Rumah Tangga Perikanan (RTP) sebanyak 36,59\% dari jumlah keseluruhan RTP di Kota Samarinda.

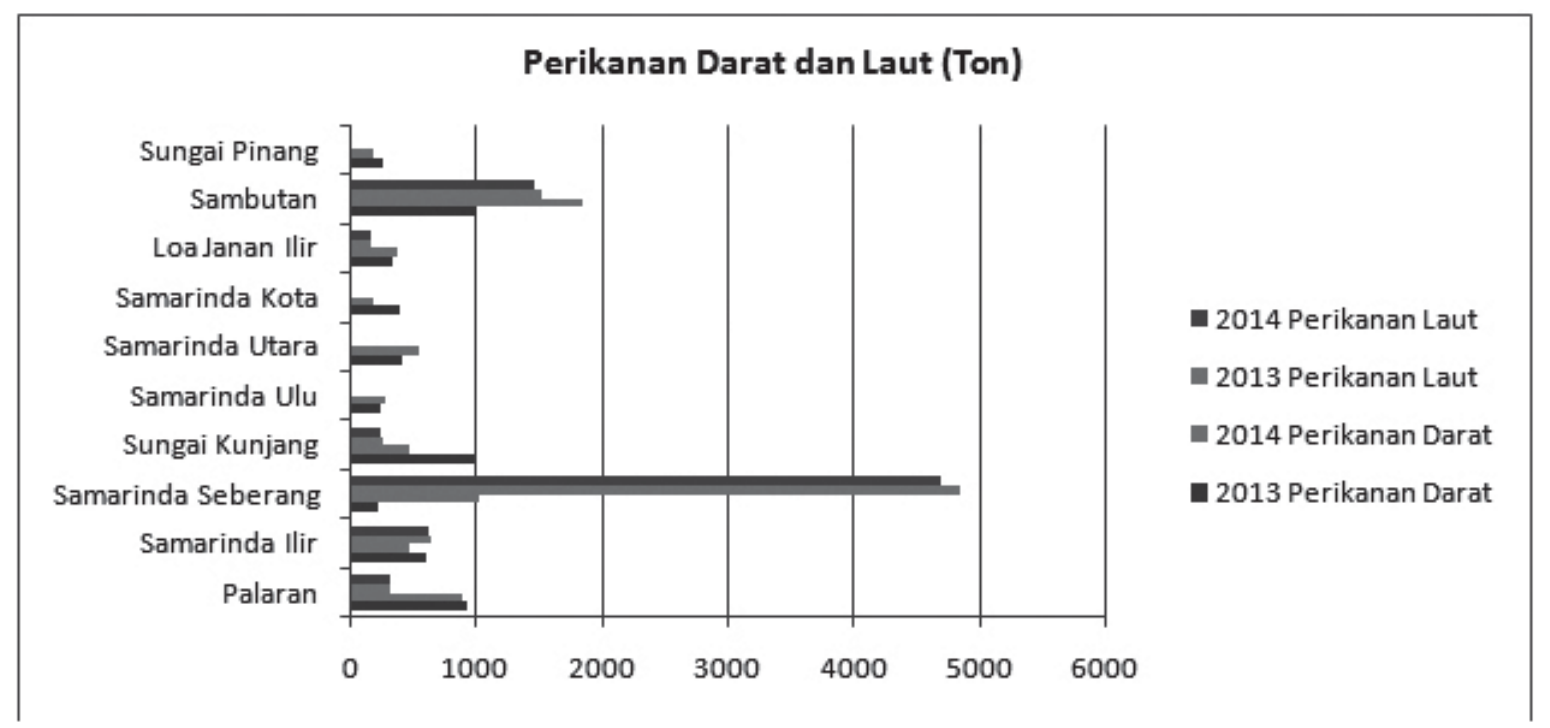

Sumber: Data diolah

Gambar 3.

Potensi Perikanan Darat dan Laut per Kecamatan di Kota Samarinda 
Potensi ternak dimiliki hampir diseluruh kecamatan yang ada di Samarinda, kecuali Samarinda Kota. Kecamatan yang memiliki jumlah populasi ternak yang meningkat dari 2013 sampai dengan 2014 adalah Samarinda Utara, Loa Janan Ilir, Sambutan dan Sungai Pinang.

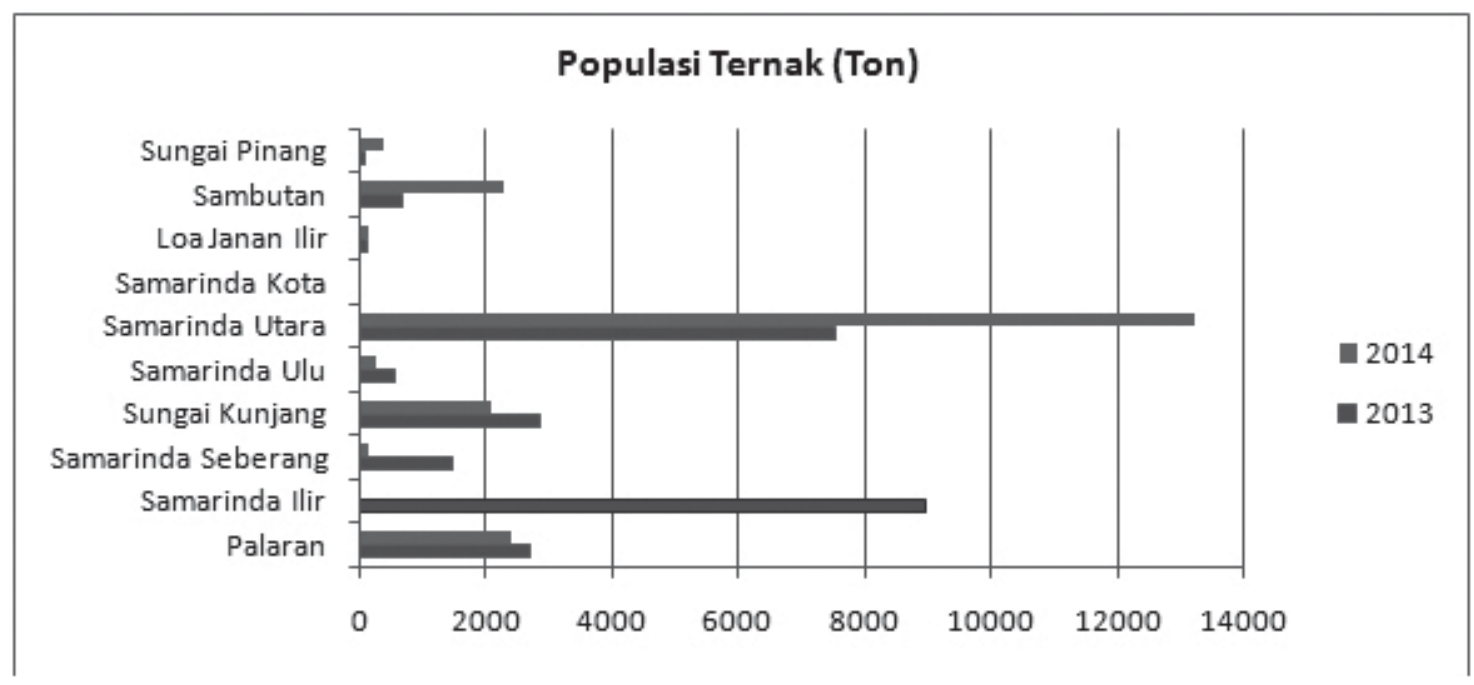

Sumber: Data diolah

Gambar 4.

Populasi Ternak per Kecamatan di Kota Samarinda

Selain memiliki potensi ternak yang terbesar dan selalu meningkat setiap tahunnya, Kecamatan Samarinda Utara juga memiliki populasi unggas yang terbesar, diikuti oleh Kecamatan Palaran dan Sungai Kunjang.

Tabel 5.

Populasi Ternak per Kecamatan di Kota Samarinda

\begin{tabular}{|l|r|r|}
\hline \multirow{2}{*}{ Kecamatan } & \multicolumn{2}{c|}{ Unggas(Ekor) } \\
\cline { 2 - 3 } & \multicolumn{1}{|c|}{$\mathbf{2 0 1 3}$} & \multicolumn{1}{c|}{$\mathbf{2 0 1 4}$} \\
\hline Palaran & 1.277 .656 & 1.359 .707 \\
\hline Samarinda Ilir & 244.726 & 163.859 \\
\hline Samarinda Seberang & 236.090 & 251.665 \\
\hline Sungai Kunjang & 332.334 & 340.214 \\
\hline Samarinda Ulu & 50160 & 28.339 \\
\hline Samarinda Utara & 7.413 .733 & 7.632 .029 \\
\hline Samarinda Kota & & 23.322 \\
\hline Loa Janan Ilir & - & 16.358 \\
\hline Sambutan & - & 97.951 \\
\hline Sungai Pinang & - & 227.464 \\
\hline
\end{tabular}

Sumber: Data diolah 
Sebagai kecamatan terluas di Samarinda, Samarinda Utara dan Palaran memiliki luas lahan panen padi dan perkebunan terluas. Selain itu, di sub sector peternakan, baik sapi maupun unggas, Kecamatan Sebatik Utara juga lebih menghasilkan. Dalam RTRW Kota Samarinda juga mengarahkan sector pertanian yang cukup luas di Samarinda Utara dan Palaran.

\section{Sektor Industri}

Di sektor industri, jumlah industri kecil dan rumah tangga Kota Samarinda di tahun 2013 mengalami kenaikan dibanding tahun sebelumnya, namun di tahun 2014, ada tiga kecamatan yaitu Samarinda Seberang, Palaran dan Sungai Pinang yang mengalami penurunan. Salah satu visi Kota Samarinda kedepan adalah menjadi kota industri. Penurunan jumlah industri kecil dan rumah tangga ini perlu ditangani untuk menunjang pencapaian visi Kota Samarinda. Adapun industri kecil dan rumah tangga yang dimaksud meliputi bata, pakaian, mebel dan atap.

Tabel 6.

Industri Kecil dan Rumah Tangga per Kecamatan di Kota Samarinda

\begin{tabular}{|l|r|r|r|}
\hline \multirow{2}{*}{\multicolumn{1}{|c}{ Kecamatan }} & \multicolumn{2}{c|}{ Industri Kecil dan Rumah Tangga (unit) } \\
\cline { 2 - 4 } & 2012 & $\mathbf{2 0 1 3}$ & $\mathbf{2 0 1 4}$ \\
\hline Samarinda Kota & - & - & - \\
\hline Samarinda Ulu & - & - & - \\
\hline Samarinda Ilir & - & - & - \\
\hline Samarinda Seberang & & 431 & 348 \\
\hline Samarinda Utara & 62 & 49 & 49 \\
\hline Palaran & 115 & 39 & 26 \\
\hline Sungai pinang & - & 38 & 37 \\
\hline Sungai kunjang & - & - & - \\
\hline Sambutan & - & - & - \\
\hline Loa Janan Ilir & 49 & 41 & 47 \\
\hline
\end{tabular}

Sumber: Data diolah

\section{Sektor Perdagangan dan Restoran}

Keberadaan toko dan restoran yang ada di di Samarinda, selama dua tahun terakhir selalu meningkat hampir si seluruh kecamatan, kecuali Palaran dan Samarinda Seberang. Sebagai kecamatan terpadat di Samarinda, Samarinda Ulu juga terbanyak dalam keberadaan warung dan toko. Sedangkan kecamatan dengan keberadaan restoran terbanyak di Kecamatan Samarinda Ilir. Jumlah restoran memiliki trend positif pada hampir seluruh kecamatan, kecuali Palaran dan Samarinda Seberang. 


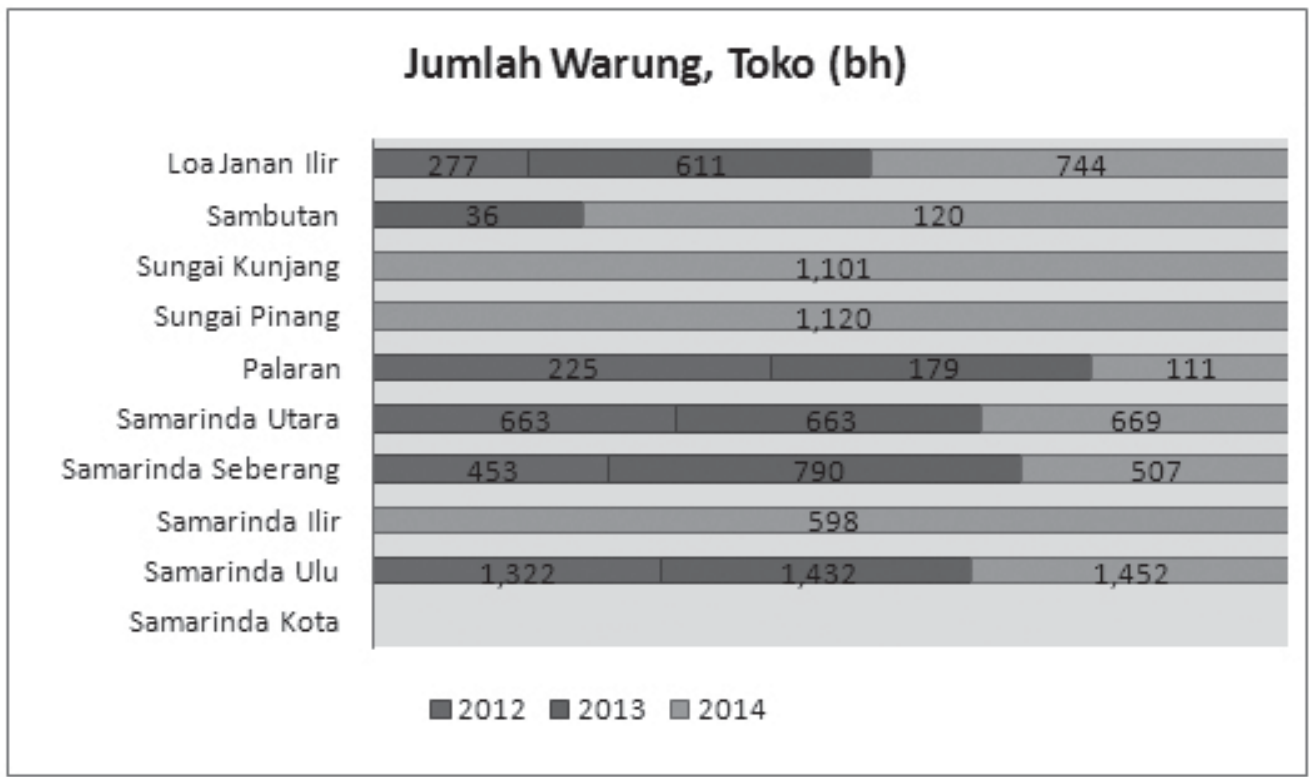

Sumber: Data diolah

Gambar 5.

Jumlah Warung dan Toko per Kecamatan di Kota Samarinda

\section{Pengangkutan dan Komunikasi}

Jumlah angkutan jalan raya dan angkutan sungai dua tahun terakhir trend-nya selalu meningkat. Fenomena ini tentunya berkaitan erat dengan jumlah penduduk Kota Samarinda yang selalu meningkat setiap tahunnya. Adapun meningkatnya jumlah angkutan sungai sangat terkait dengan meningkatnya jumlah masyarakat yang bermata pencaharian menangkap ikan.

Tabel 7.

Jumlah Angkutan Jalan Raya dan Sungai per Kecamatan di Kota Samarinda

\begin{tabular}{|l|c|c|c|c|c|c|}
\hline \multirow{2}{*}{\multicolumn{1}{|c}{ Kecamatan }} & \multicolumn{3}{|c|}{ Angkutan Jalan Raya (unit) } & \multicolumn{3}{c|}{$\begin{array}{c}\text { Angkutan Sungai, Danau } \\
\text { dil ( unit) }\end{array}$} \\
\cline { 2 - 8 } & $\mathbf{2 0 1 2}$ & $\mathbf{2 0 1 2}$ & $\mathbf{2 0 1 3}$ & $\mathbf{2 0 1 2}$ & $\mathbf{2 0 1 3}$ & $\mathbf{2 0 1 4}$ \\
\hline Samarinda Kota & - & - & - & - & - & - \\
\hline Samarinda Ulu & 44.727 & 48.044 & 52.301 & - & - & - \\
\hline Samarinda Ili & - & - & - & - & - & - \\
\hline Samarinda Seberang & 8.050 & 9.200 & 11.553 & 236 & 298 & 213 \\
\hline Samarinda Utara & - & - & - & 44 & 44 & 52 \\
\hline Palaran & - & - & - & 144 & 147 & 203 \\
\hline Sungai pinang & - & - & - & - & - & - \\
\hline Sungai kunjang & - & - & - & - & - & - \\
\hline Sambutan & - & 9.581 & 10.859 & - & 116 & 128 \\
\hline Loa Janan Ilir & 13.458 & 14.257 & 15.558 & 128 & 125 & 122 \\
\hline
\end{tabular}

Sumber: Data diolah 
Jumlah warung telekomunikasi (wartel) yang ada di Samarinda sangat sedikit, dari sepuluh kecamatan, hanya Kecamatan Sambutan yang masih memiliki wartel, kondisi ini tentu sangat terkait dengan hampir semua masyarakat saat ini sudah memiliki telepon rumah bahkan telepon selular. Keberadannya Kantor pos diperlukan untuk mengirimkan barang maupun paket keluar daerah, sehingga hampir diseluruh kecamatan memiliki kantor pos.

Tabel 8.

Jumlah Angkutan Jalan Raya dan Sungai per Kecamatan di Kota Samarinda

\begin{tabular}{|c|c|c|c|c|c|c|}
\hline \multirow{2}{*}{ Kecamatan } & \multicolumn{3}{|c|}{$\begin{array}{c}\text { Warung } \\
\text { Telekomunikasi (unit) }\end{array}$} & \multicolumn{3}{|c|}{$\begin{array}{c}\text { Pos } \\
\text { (unit) }\end{array}$} \\
\hline & 2012 & 2013 & 2014 & 2012 & 2013 & 2014 \\
\hline Samarinda Kota & - & - & - & - & - & - \\
\hline Samarinda Ulu & - & - & - & 2 & 2 & 2 \\
\hline Samarinda Ilir & - & - & - & 1 & 1 & 1 \\
\hline Samarinda Seberang & - & - & - & 2 & 2 & 2 \\
\hline Samarinda Utara & - & - & - & 2 & 2 & 2 \\
\hline Palaran & - & - & - & 1 & 1 & 1 \\
\hline Sungai pinang & - & - & - & 1 & 1 & 1 \\
\hline Sungai kunjang & - & - & - & 1 & 1 & 1 \\
\hline Sambutan & - & 10 & 10 & - & 1 & 2 \\
\hline Loa Janan Ilir & - & - & - & 1 & 1 & 1 \\
\hline
\end{tabular}

Sumber: Data diolah

\section{Pemetaan Potensi Kecamatan}

Pemetaan potensi ekonomi pada masing-masing kecamatan dikelompokkan berdasarkan tiga cluster. Pembuatan cluster ini dilakukan berdasarkan dominasi dan pertumbuhan sektor ekonomi di setiap kecamatan. Dengan adanya pengelompokkan sektor ekonomi, diharapkan dapat memudahkan pemerintah untuk mengambil kebijakan dan fokus dalam pengembangan sektor yang dapat didorong maupun dikembangkan dimasa yang akan datang. Adapun tiga cluster yang dimaksud adalah sebagai berikut:

1. Leading cluster, yaitu dimana potensi ekonomi yang ada di kecamatan menjadi unggulan;

2. Potential cluster, dimana potensi ekonomi yang ada di kecamatan bukan yang menjadi unggulan, namun memiliki potensi untuk terus dikembangkan;

3. Opportunity cluster, dimana potensi ekonomi yang ada di kecamatan tidak memiliki nilai, namun jika dilihat dari aspek lainnya seperti kondisi geografisnya, maka dapat dipertimbangkan untuk dikembangkan 
Tabel 9.

Pemetaan Potensi Ekonomi Kecamatan di Kota Samarinda

\begin{tabular}{|c|c|c|c|}
\hline \multirow[t]{2}{*}{ Kecamatan } & \multicolumn{3}{|c|}{ Cluster } \\
\hline & Leading & Potential & Opportunity \\
\hline Samarinda Kota & $\begin{array}{l}\text { Perikanan Darat; } \\
\text { Unggas; } \\
\text { Perdagangan Besar dan Eceran* }\end{array}$ & Restoran; Pos & \\
\hline Samarinda Ulu & Perdagangan Besar dan Eceran & $\begin{array}{lr}\text { Tanaman } & \text { Pangan; } \\
\text { Perkebunan; } & \text { Perikanan } \\
\text { Darat; Temak; Unggas; } \\
\text { Restoran; Pos }\end{array}$ & $\begin{array}{l}\text { Industri Kecil dan } \\
\text { Rumah Tangga }\end{array}$ \\
\hline Samarinda Ilir & $\begin{array}{l}\text { Perikanan Darat; Temak; } \\
\text { Unggas; Perdagangan Besar dan } \\
\text { Eceran; Restoran }\end{array}$ & Perikanan Laut; Pos & $\begin{array}{l}\text { Industri Kecil } \\
\text { Rumah Tangga }\end{array}$ \\
\hline $\begin{array}{l}\text { Samarinda } \\
\text { Seberang }\end{array}$ & $\begin{array}{l}\text { Perikanan Laut; Perikanan } \\
\text { Darat; Unggas; Perdagangan } \\
\text { Besar dan Eceran; Angkutan } \\
\text { Sungai; Industri Kecil dan } \\
\text { Rumah Tangga }\end{array}$ & $\begin{array}{lr}\text { Tanaman } & \text { Pangan; } \\
\text { Perkebunan; } & \text { Temak; } \\
\text { Restoran; Pos } & \end{array}$ & \\
\hline $\begin{array}{l}\text { Samarinda } \\
\text { Utara }\end{array}$ & $\begin{array}{l}\text { Tanaman Pangan; Perkebunan; } \\
\text { Temak; Unggas; Perdagangan } \\
\text { Besar dan Eceran; Industr } \\
\text { Kecil dan Rumah Tangga }\end{array}$ & $\begin{array}{l}\text { Perikanan Darat; Restoran; } \\
\text { Angkutan Sungai; Pos }\end{array}$ & - Angkutan Darat \\
\hline Palaran & $\begin{array}{l}\text { Tanaman Pangan; Perkebunan; } \\
\text { Perikanan Darat; Temak; } \\
\text { Unggas; Restoran; Angkutan } \\
\text { Sungai; Industr Kecil dan } \\
\text { Rumah Tangga }\end{array}$ & $\begin{array}{lr}\text { Perikanan } & \text { Laut; } \\
\text { Perdagangan } & \text { Besar dan } \\
\text { Eceran; Pos } & \end{array}$ & \\
\hline Sungai Pinang & $\begin{array}{l}\text { Unggas; Perdagangan Besar dan } \\
\text { Eceran }\end{array}$ & $\begin{array}{l}\text { Perikanan Darat; Temak; } \\
\text { Restoran; Pos; Industri } \\
\text { Kecil dan Rumah Tangga }\end{array}$ & $\begin{array}{l}\text { Tanaman pangan; } \\
\text { Perkebunan }\end{array}$ \\
\hline Sungai Kunjang & $\begin{array}{l}\text { Perikanan Darat; Temak; } \\
\text { Unggas; Perdagangan Besar dan } \\
\text { Eceran }\end{array}$ & $\begin{array}{l}\text { Perkebunan; Perikanan } \\
\text { Laut; Restoran; Pos }\end{array}$ & Tanaman Pangan \\
\hline Sambutan & \begin{tabular}{lr}
\multicolumn{3}{l}{ Tanaman Pangan; } & Perkebunan; \\
Perikanan Laut & Perikanan \\
Darat; Temak; & Angkutan \\
Sungai; & Wanung \\
Telekomunikasi &
\end{tabular} & $\begin{array}{lr}\text { Unggas; } & \text { Perdagangan } \\
\text { Besar dan } & \text { Eceran; } \\
\text { Restoran; Pos } & \end{array}$ & $\begin{array}{l}\text { Industri Kecil } \\
\text { Rumah Tangga }\end{array}$ \\
\hline Loa Janan Ilir & $\begin{array}{l}\text { Perikanan Darat; Tanaman } \\
\text { Pangan; Perdagangan Besar dan } \\
\text { Eceran; Industri Kecil dan } \\
\text { Rumah Tangga }\end{array}$ & $\begin{array}{l}\text { Perikanan Laut; Temak; } \\
\text { Unggas; Restoran; Pos }\end{array}$ & \\
\hline
\end{tabular}

Dari tabel 9 dapat dilihat potensi ekonomi di masing-masing kecamatan berdasarkan clusternya. Untuk Kecamatan Samarinda Kota, sektor ekonomi yang menjadi leading adalah perikanan darat serta ternak unggas, sedangkan potential clusternya adalah restoran dan pos. Dari data tidak disebutkan potensi perdagangan besar dan eceran, namun sektor perdagangan besar dan eceran juga dimasukkan ke dalam leading cluster di Kecamatan Samarinda Kota dikarenakan di Kecamatan 
Samarinda Kota, tepatnya Kelurahan Pasar Pagi terdapat pasar, toko dan merupakan pusat perdagangan. Kondisi ini juga sejalan dengan rencana pola kawasan Kota Samarinda untuk Kecamatan Samarinda Kota.

Kecamatan Samarinda Ulu merupakan kecamatan dengan kepadatan penduduk tertinggi, namun dalam rencana pola ruang kawasan budidaya Kota Samarinda, ternyata Kecamatan Samarinda Ulu tidak masuk dalam kategori kawasan perumahan dengan kepadatan tertinggi, tapi masuk dalam kategori sedang. Penempatan ini tentunya dapat menyebabkan perencanaan tidak tepat sasaran. Jumlah penduduk yang tinggi tersebut menjadikan sektor perdagangan masuk kedalam leading cluster di Kecamatan Samarinda Ulu, sedangkan yang termasuk dalam potential cluster adalah tanaman pangan, perkebunan, perikanan darat, ternak, unggas, restoran dan pos. Karena di Kecamatan Samarinda Ulu terdapat potensi perikanan darat, kemungkinan di kecamatan ini bisa didorong untuk menghidupkan sektor industri, khususnya pengolahan hasil perikanan. Sektor industri ini dimungkinkan untuk dikembangkan karena Kecamatan Samarinda Ulu masuk kedalam kriteria lokasi industri, yaitu jarak ke pusat kota dekat, kemudahan memperoleh tenaga kerja mengingat kepadatan penduduknya tinggi, serta aksesibilitas untuk mencari bahan baku dan memasarkan hasil produksi mudah.

Selanjutnya untuk Samarinda Ilir, sektor pertanian (perikanan darat, ternak, dan unggas), perdagangan besar dan eceran serta restoran masuk kedalam leading cluster. Kondisi ini sedikit berbeda dengan rencana pola kawasan budidaya Kota Samarinda, dimana di Kecamatan Samarinda Ilir tidak direncanakan kawasan untuk pertanian. Padahal jika dilihat dari data potensi ekonominya, Kecamatan Samarinda Ilir memiliki potensi yang besar dalam pertanian. Adapun perikanan laut dan pos masuk kedalam potential cluster. Sama dengan Kecamatan Samarinda Utara, di Kecamatan Samarinda Ilir juga dimungkinkan untuk dikembangkan industri kecil dan rumah tangga, khususnya pengolahan hasil perikanan, karena potensi perikanan laut di Kecamatan Samarinda Ilir relatif besar, sehingga bahan bakunya mudah didapat.

Kecamatan Samarinda Seberang merupakan salah satu kecamatan yang terbentuk bersamaan dengan berdirinya Kota Samarinda. Kecamatan ini memiliki potensi pertanian (perikanan laut, perikanan darat dan ungags), perdagangan besar dan eceran, angkutan sungai, serta industri kecil dan rumah tangga, yang masuk kedalam leading cluster. Untuk potensi angkutan sungai di kecamatan ini relatif besar, karena kondisi Samarinda Seberang yang berada di pinggir Sungai Mahakam. Adapun sektor ekonomi yang masuk dalam ketegori potential cluster di Kecamatan Samarinda Seberang adalah pertanian (tanaman pangan, perkebunan dan ternak), restoran dan pos.

Kecamatan Samarinda Utara merupakan sentral penghasil pertanian, yaitu tanaman pangan, perkebunan, peternakan dan unggas. Kondisi ini tentunya bisa dimaklumi karena sebagai penghasil tanaman pangan dan perkebunan, menjadikan Kecamatan Samarinda Utara mudah untuk mendapatkan bahan pakan untuk ternak, sehingga produksi ternak di kecamatan ini juga tinggi. Selain pertanian, yang termasuk kedalam leading cluster adalah sektor perdagangan besar dan eceran serta industri kecil dan rumah tangga. Adapun yang masuk kedalam potential cluster adalah perikanan darat dan restoran, sedangkan yang masuk kedalam opportunity cluster adalah angkutan darat. Hal ini terkait dengan telah dibangunnya bandara di Kelurahan Sei Siring.

Selanjutnya sebagai kecamatan dengan kepadatan penduduk paling kecil, yaitu 246 jiwa/ km2, menjadikan Kecamatan Palaran sebagai salah satu penyumbang sektor pertanian terbesar, karena lahannya masih dimungkinkan untuk dikembangkan pada sektor tersebut. Kondisi ini sejalan dengan rencana pola ruang kawasan budi daya Kota Samarinda, dimana rencana ruang pertanian di Palaran adalah terbesar kedua setelah Kecamatan Samarinda Utara. Selain pertanian, yang termasuk kedalam leading cluster di kecamatan ini adalah restoran, industri kecil dan rumah tangga serta 
angkutan sungai. Sedangkan yang termasuk kedalam potential cluster adalah perikanan laut, perdagangan besar dan eceran serta pos.

Untuk Kecamatan Sungai Pinang, sektor pertanian yang termasuk kedalam leading cluster adalah unggas, sedangkan tanaman pangan dan perkebunan di kecamatan ini belum ada. Namun demikian sebenarnya sektor ini dapat dikembangkan (opportunity cluster), namun dengan perencanaan yang matang, karena kepadatan penduduk di Kecamatan Sungai Pinang merupakan yang tertinggi kelima di Samarinda. Akan tetapi mengingat kondisi geografis seperti kemerengan lereng (8-25\%), serta jenis tanahnya adalah padsolik, yaitu jenis tanah yang cocok dikembangkan sebagai pertanian, sehingga kedepan potensi pertanian (tanaman pangan dan perkebunan) masih mungkin untuk dikembangkan. Menjadikan pertanian (tanaman pangan dan perkebunan) sebagai opportunity cluster sejalan dengan rencana pola ruang kawasan budidaya Kota Samarinda, dimana Kecamatan Samarinda Ilir 9,33\% kawasannya diperuntukkan untuk pertanian. Adapun sektor yang masuk kedalam potential cluster adalah pertanian (perikanan darat dan ternak), restoran, pos serta industri kecil dan rumah tangga.

Pada Kecamatan Sungai Kunjang, sektor pertanian yang masuk kedalam leading cluster adalah pertanian (perikanan darat, ternak serta ungags). Selain itu sektor perdagangan besar dan eceran juga termasuk kedalam leading cluster. Jumlah warung dan toko di kecamatan ini termasuk salah satu yang terbanyak, terbukti dengan semakin banyaknya bermunculan toko kelontong di Kecamatan Sungai Kunjang. Adapun yang termasuk kedalam potential cluster di Kecamatan Sungai Kunjang adalah pertanian (perkebunan dan perikanan laut), restoran dan pos. Sedangkan untuk tanaman pangan, sama dengan Kecamatan Sungai Pinang, masih ada peluang (opportunity cluster) untuk dikembangkan, tentunya dengan perencanaan yang matang mengingat Kecamatan Sungai Kunjang memiliki kepadatan penduduk tertinggi setelah Kecamatan Sungai Pinang. Jenis tanah di Kecamatan Sungai Kunjang adalah padsolik dan organosal. Menjadikan tanaman pangan sebagai opportunity cluster juga sejalan dengan yang direncanakan dalam tata ruang wilayah, dimana 1,33\% kawasan di Kecamatan Sungai Kunjang diperuntukkan untuk kawasan pertanian.

Selanjutnya untuk Kecamatan Sambutan, saat ini masih memiliki tingkat kepadatan penduduk terendah ketiga setelah Samarinda Utara, yaitu 479 jiwa/km2, oleh sebab itu sektor pertanian seperti tanaman pangan, perkebunan, perikanan laut, perikanan darat serta ternak menjadi leading cluster di kecamatan ini. Selain itu Sambutan merupakan satu-satunya kecamatan yang masih memiliki potensi ekonomi dari komunikasi (wartel). Adapun yang termasuk dalam potential cluster di Kecamatan Sambutan adalah unggas, perdagangan besar dan eceran, restoran serta pos. Sama dengan kecamatan Samarinda Ulu dan Samarinda Ilir, Kecamatan Sambutan juga memiliki kemungkinan (opportunity cluster) untuk didorong lahirnya industri kecil dan rumah tangga, khususnya pengolahan hasil perikanan, karena Kecamatan Sambutan memiliki potensi perikanan laut terbesar setelah Kecamatan Samarinda Seberang. Kondisi ini masih belum ditangkap dalam pentaan ruang Kota Samarinda, karena dalam rencana pola ruang kawasan budi daya Kecamatan Sambutan belum ada kawasan yang diperuntukkan untuk industri.

Kecamatan Samarinda Ilir merupakan pemekaran dari Kecamatan Samarinda Seberang yang merupakan pintu gerbang menuju Kota Samarinda. Pada Kecamatan Loa Janan Ilir sektor pertanian yang masuk dalam leading cluster adalah perikanan darat dan tanaman pangan. Selain itu sektor lain yang termasuk dalam leading cluster adalah perdagangan besar dan eceran serta industri kecil dan rumah tangga. Kondisi ini ditunjukkan dengan banyaknya toko dan warung di Kecamatan Loa Janan Ilir yang setiap tahun terus bertambah. Adapun sektor ekonomi yang termasuk kedalam potential cluster adalah pertanian (perikanan laut, ternak dan unggas), restoran serta pos. 


\section{E. PENUTUP}

Pemetaan potensi sumberdaya ekonomi daerah sangat penting bagi perencanaan pembangunan daerah serta optimalisasi ruang gerak ekonomi daerah dalam mewujudkan kesejahteraan ekonomi masyarakat. Disimpulkan bahwa pemetaan pembangunan wilayah kecamatan di Kota Samarinda berdasarkan potensi ekonomi yang dimilikinya dapat dikelompokkan atau ditetapkan ke dalam 3 cluster ekonomi, yaitu Leading Cluster, Potential Cluster, dan Opportunity Cluster. Pemetaan potensi ekonomi berbasis kecamatan dirumuskan dengan tetap memperhatikan rencana tata ruang Kota Samarinda secara umum dan perencanaan kawasan budidaya masing-masing kecamatan secara khusus. Dengan demikian, pola perencanaan dan pengembangan potensi masing-masing kecamatan dapat terintegrasi dan tepat guna.Pergeseran perekonomian Samarinda menjadi kota perdagangan menunjukkan potensi besar Samarinda terhadap sektor non SDA (batubara dan kayu), dan berpotensi meningkat dengan ketergantungan daerah (kabupaten/Kota) sekitarnya

Dalam rangka mewujudkan pembangunan yang merata dan berkesinambungan pada masingmasing kecamatan di Kota Samarinda, beberapa alternatif kebijakan yang dapat direkomendasikan antara lain adalah fokus arah pembangunan daerah sebaiknya mempertimbangkan cluster ekonomi yang telah dipetakan tersebut khususnya pada area potential cluster dan opportunity cluster. Hal ini mengingat kelompok potensi ekonomi tersebut membutuhkan dukungan kebijakan dan political will pemerintah daerah sehingga cluster-cluster tersebut dapat menjadi leading sector di masingmasing kecamatan. Agar pelaksanaan pembangunan menjadi lebih konsisten sebaiknya pemerintah daerah menetapkan dokumen perencanaan dan penganggaran daerah secara annual-basis program dan kegiatan yang mendorong peningkatan potential cluster dan opportunity cluster pada masingmasing kecamatan. Masih luasnya wilayah Kota Samarinda juga menuntut agar penyebaran pengembangan ekonomi daerah tidak menumpuk di pusat kota dan menghindari metropolitantrap, sehingga pemerintah daerah perlu mengatur regulasi usaha ekonomi pada wilayah-wilayah penunjang pusat kota atau menumbuhkan pusat-pusat kota baru. Dengan demikian, diharapkan penumpukan beban ekonomi dan sosial tidak lagi bertumpu pada satu kecamatan tertentu saja. Selain itu, untuk mendukung perumusan dan pengambilan kebijakan ekonomi daerah, diperlukan bank data yang lengkap terkait potensi ekonomi masing-masing kecamatan di Kota Samarinda.

\section{DAFTAR PUSTAKA}

Adisasmita, Rahardjo. (2011). Pembiayaan Pembangunan Pembangunan Daerah. Yogyakarta. Graha Ilmu

BPS Kota Samarinda. (2015). Kecamatan Loa Janan Ilir Dalam Angka. BPS Kota Samarinda BPS Kota Samarinda. (2015). Kecamatan Palaran Dalam Angka. BPS Kota Samarinda BPS Kota Samarinda. (2015). Kecamatan Samarinda Utara Dalam Angka. BPS Kota Samarinda BPS Kota Samarinda. (2015). Kecamatan Samarinda Ilir Dalam Angka. BPS Kota Samarinda

BPS Kota Samarinda. (2015). Kecamatan Samarinda Seberang Dalam Angka. BPS Kota Samarinda

BPS Kota Samarinda. (2015). Kecamatan Samarinda Ulu Dalam Angka. BPS Kota Samarinda BPS Kota Samarinda. (2015). Kecamatan Sambutan Kota Dalam Angka. BPS Kota Samarinda BPS Kota Samarinda. (2015). Kecamatan Sungai Kunjang Dalam Angka. BPS Kota Samarinda 
BPS Kota Samarinda. (2014). Produk Domestik Regional Bruto Kota Samarinda Menurut Lapangan Usaha Tahun 2010-2013. BPS Kota Samarinda

BPS Kota Samarinda. (2015). Samarinda Dalam Angka 2015. BPS Kota Samarinda

BPS Kota Samarinda. (2014). Samarinda Dalam Angka 2014. BPS Kota Samarinda

BPS Kota Samarinda. (2015). Statistik Daerah Kecamatan Loa Janan Ilir. BPS Kota Samarinda BPS Kota Samarinda. (2015). Statistik Daerah Kecamatan Palaran. BPS Kota Samarinda BPS Kota Samarinda. (2015). Statistik Daerah Kecamatan Samarinda Ilir. BPS Kota Samarinda

BPS Kota Samarinda. (2015). Statistik Daerah Kecamatan Samarinda Kota. BPS Kota Samarinda

BPS Kota Samarinda. (2015). Statistik Daerah Kecamatan Samarinda Seberang. BPS Kota Samarinda

BPS Kota Samarinda. (2015). Statistik Daerah Kecamatan Samarinda Ulu. BPS Kota Samarinda

BPS Kota Samarinda. (2015). Statistik Daerah Kecamatan Samarinda Utara. BPS Kota Samarinda

BPS Kota Samarinda. (2015). Statistik Daerah Kecamatan Sambutan. BPS Kota Samarinda

BPS Kota Samarinda. (2015). Statistik Daerah Kecamatan Sungai Kunjang. BPS Kota Samarinda

BPS Kota Samarinda. (2015). Statistik Daerah Kecamatan Sungai Pinang. BPS Kota Samarinda

BPS Kota Samarinda. (2015). Statistik Daerah Kecamatan Samarinda Kota. BPS Kota Samarinda

Direktur Jenderal Penataan Ruang Departemen Permukiman dan Prasarana Wilayah. (2003). Pengembangan Wilayah dan Penataan Ruang di Indonesia: Tinjauan Teoritis dan Praktis. Disajikan dalam Studium General Sekolah Tinggi Nasional (STTNAS) di Yogyakarta, 1 September 2003

Fitriana, Elvie Dyah. Bambang Supriyono. Farida Nurani. (2013). Implementasi Kebijakan Tata Ruang Wilayah Dalam Mewujudkan, Pembangunan Kota Berkelanjutan ( Studi di Kab. Magetan). Jurnal Administrasi Publik(JAP),Vol.2, No. 2 -2013, Jurusan Administrasi Publik, Fakultas Ilmu Administrasi, Universitas Brawijaya, Malang

Ghalib, Rusli. (2005). Ekonomi Regional. Bandung. Pustaka Ramadhan

Iryanto. (2006). Perencanaan Pembangunan Kabupaten/Kota Melalui Pendekatan Wilayah dan Kerjasama Antardaerah. Jurnal Perencanaan \& Pengembangan Wilayah WAHANA HIJAU Volume 1 Nomor 3. Universitas Sumatera Utara

Kuncoro, Mudrajad. (2012). Perencanaan Daerah Bagaimana Membangun Ekonomi Lokal, Kota dan Kawasan?. Jakarta. Salemba Empat

Laporan Akhir Revisi Materi Teknis dan Album Peta RTRW Kota Samarinda Tahun 2013-2033

Lembaga Administrasi Negara. (2014). Kajian Integrasi Sistem Perencanaan Dan Penganggaran. Jakarta. Lembaga Administrasi Negara Deputi Bidang Kajian Kebijakan Pusat Kajian Sistem dan Hukum Administrasi Negara. 
Wibawa, Samodra. (2012). Mengelola Negara. Yogyakarta. Gava Media.

Widodo, Tri. (2006). Perencanaan Pembangunan: Aplikasi Komputer (Era Otonomi Daerah). Yogyakarta. UPP STIM YKPN Yogyakarta 